\title{
Analisis Penentuan Wilayah Manajemen Kebakaran Berdasarkan Waktu Tanggap (Response Time) di Kabupaten Lombok Barat
}

\author{
Fariz Primadi H dan Ima Rahmawati S \\ Dosen Program Studi Perencanaan Wilayah \& Kota Fakultas Teknik Universitas. Muhammadiyah Mataram \\ *fariz.primadi@gmail.com
}

\section{INFO ARTIKEL}

Riwayat Artikel:

Diterima:2-12-2016

Disetujui:11-1-2017

\section{Kata Kunci:}

Wilayah manajmen kebakaran waktu tanggap

\section{A. PENDAHULUAN}

Untuk menjamin keandalan bangunan gedung dan lingkungannya maka bangunana Gedung dan lingkungannnya harus terintegrasi secara aktif dan pasif terhadap sistem proteksi kebakarn kota sehingga mampu menjamin efektifitas dan efesiensi dari pencegaha dan penanggulangan terhadap bahaya kebakaran di perkotaan.

Dinamika pertumbuhan wilayah yang terus berkembang dan berdampak pada semakin tingginya tingkat kebakaran disatu sisi pembangunana yang diselengarakan belum sepenuhnya dilaksanakan sesuai dengan peraturan perundanga yang berlaku, disamping itu pembangunan sarana dan prasarana pencegahan dan penanggulangan bahaya
ABSTRAK

Abstrak: Tujuan dari penelitian ini diharapkan dapat menentukan sesuatu penentuan penanganan kebakaran berdasarkan wilayah manajmen kebakaran yang didasarkan dalam waktu tanggap (response time) Instansi Pemadam Kebakaran (IPK). Oleh karana itu perlu disususn sebuah pendekatan proteksi kebakaran yang memanfaatkan suatu pengelolaan dengan bassis wilayah, sehingga kejadian kebakaran dapat di tanggulangi dan meminimalisir kerugian yang di timbulkan. Metode penelitian yang dipergunakan dengan menggunakan metode deskriptif kualitatif, dengan analisis fisik spatial dan analisis regulasi terkait proyeksi kebakaran. Hasil dalam penelitian ini menentapkan 8 wilayah manajmen kebakaran di kabupaten lombok timur berdasarkan indikator kewilayahannya sehingga diharapkan Abstract: The purpose of this study is expected to be able to determine what determines the handling of fires based on the area of fire management based on the response time of the Fire Department (IPK). By karana it needs to be followed by a fire protection approach that utilizes a management with a regional bassist, so that fire events can be addressed and minimize the losses caused. The research method used is using qualitative descriptive method, with spatial physical analysis and analysis of regulations related to fire projections. The results in this study determined 8 fire management areas in East Lombok regency based on their regional indicators so that the expected handling of fires in East Lombok Regency could be handled optimally.

kebakaranpun tidak sebanding dengan pertumbuhan wilayah itu sendiri.

Seperti diketahui Bersama bahwasanya kebakaran saat saat ini sangat meresahkan banyak pihak, dimana angka kebakaran pada bangunan dan lingkungan diperkotaan masih cukup tinggi. Selain itu keberadaan pusat pusat kegiatan wilayah yang tersebar di kabupaten Lombok timur menyebabkan tindakan pencegahan dan penanggulangan kebakaran tidak berlangsung maksimal, diperparah lagi dengan sirkulasi dan aksesibilitas petugas PMK yang terbatas akibat berkembangnya pembangunan kawasan terbangun yang tidak sesuai ketetntuan teknis, baik itu pemanfaatannya, masih banyak yang tidak sesuai dengan fungsi serta ketentuan teknis serta produk 
pengaturan tentang pengamanan bahaya kebakaran yang bersifat nasional seperti Standar dan petunjuk teknis belum sepenuhnya di tindak lanjuti oleh pemerintah daerah.

Jika ditelik lebih dalam, kemempuan kualitas/ kuantitas dan kelembagaan instansi pemadam kebakaran (IPK) dikabupaten Lombok timur masih belum memadai dalam beberapa hal tugas pokok dan fungsi dari IPK yang telah ada tidak sesuai lagi dengan konsisi perkembangan dewasa ini, sehingga infrastruktur kota belum memadai, yaitu penataan hydrant kota untuk keperluan pemadam diamana jumlah dan keterampilan personil pemadamanpun belum memadai sehingga kelembagaan dan tupoksi penanganan kebakaran masih dirasakan lemah.

Tujuan dari penelitian ini, yaitu bagaimana menetapkan suatu pengelolaan dan penangulangan bahaya kebakaran dengan pendekatan kewilayahan, Yang menentukan pengelolaannya berdasarkan waktu tanggap (Response Time) IPK di Kabupaten Lombok Timur, dengan menentukan Wilayah Manajemen Kebakaran (WMK), sehingga diharapkan penanggulangan kebakaran yang terjadi dapat ditanggulangi secara baik, optimal dan tepatwaktu, berdasarkan Kriteria yang telah ditetapkan.

\section{B. METODE PENELITIAN}

\section{Klasifikasi Kebakaran Berdasarkan Peruntuan Bangunan}

Klasifikasi kebakaran berdasarkan jenis peruntukan bangunan dikelompokkan ke dalam 5 (lima) kelas dengan nilai $3-7$. Bila terdapat lebih dari satu jenis peruntukan dalam sebuah bangunan, maka angka klasifikasi resiko bahaya kebakaran paling banyak yang digunakan untuk mewakili seluruh bangunan, pada bangunan tersebut ditentukan oleh tingkat resiko bahaya kebakaran tertinggi.

\section{a. Angka Klasifikasi Resiko Bahaya Kebakaran 3}

- Resiko berbahaya kebakaran yang paling rawan, dimana jumlah dari isi bahan mudah terbakarnya sangt tinggi dan diperkirakan berkembang sangat cepat dan mempunyai nilai pelepasan yang tinggi.

- Bangunan yang berdekatan dengan bangunan yang mempunyai angka klasifikasi resiko bahaya kebakaran 3 (jaraknya $\leq 15 \mathrm{~m}$ ) dianggap sebagai bagian dari klasifikasi tersebut.

\section{b. Angka Klasifikasi Resiko Bahaya Kebakaran 4}

- Resiko bahaya kebakaran tinggi, dimana kuantitas dan kandungan bahan mudah terbakarnya tinggi dan dapat diperkirakan berkembang cepat dan mempunyai nilai pelepasan panas tinggi.

- Bangunan yang berdekatan dengan banguanan yang mempunyai angka klasifikasi resiko bahaya kebakaran 3 (jaraknya $\leq 15 \mathrm{~m}$ )

Tabel 1

Angka Resiko Bahaya Kebakaran Sangat Tinggi (3) Dan Tinggi (4)

\begin{tabular}{|c|c|c|}
\hline \multirow{2}{*}{ No } & \multicolumn{2}{|c|}{ Peruntukan Bangunan } \\
\hline & AKR 3 & AKR 4 \\
\hline $\mathbf{1}$ & Pelabuhan & Kendang Kuda \\
\hline \multirow[t]{3}{*}{2} & Pabrik & Gudang Bahan \\
\hline & Gandum/Gudang & Bangunan, Gudang \\
\hline & Padi & $\begin{array}{l}\text { Untuk Mebel Dan } \\
\text { Umum }\end{array}$ \\
\hline 3 & Penyulingan & Pusat Perbelanjaan \\
\hline \multirow{3}{*}{4} & Pabrik/Gudang & Ruang Pamer, \\
\hline & Bahan Mudah & Auditorium, \\
\hline & Terbakar & Bioskop \\
\hline \multirow[t]{2}{*}{5} & Penggilingan Minyak & Tempat \\
\hline & Pelican & Penyimpanan \\
\hline \multirow[t]{2}{*}{6} & Tempat & Terminal \\
\hline & Penyimpanan Kayu & Pengangkutan \\
\hline 7 & Penyulingan Minyak & Pertokoan \\
\hline 8 & $\begin{array}{l}\text { Pabrik/Gudang } \\
\text { Plastic }\end{array}$ & Pelabuhan \\
\hline 9 & Penggergajian Kayu & Bengkel \\
\hline \multirow{2}{*}{10} & Tempat & Industri Kayu \\
\hline & $\begin{array}{l}\text { Penyimpanan } \\
\text { Jerami }\end{array}$ & \\
\hline
\end{tabular}

\section{c. Angka Klasifikasi Resiko Bahaya \\ Kebakaran 5}

Hunian bahaya sedang, dimana kuantitas dan kandungan bahan mudah terbakarnya sedang, tinggi tumpukan bahan mudah terbakarnya tidak melebihi dari $3,7 \mathrm{~m}$, dan dapat diperkirakan berkembang sedang dan mempunyai nilai pelepasan panas sedang.

d. Angka Klasifikasi Resiko Bahaya Kebakaran 6

Resiko bahaya kebakaran rendah, dimana kuantitas dan kandungan bahan mudah terbakarnya sedang, tinggi tumpukan bahan mudah terbakarnya tidak lebih dari $2,5 \mathrm{~m}$, dan diperkirakan berkembang sedang dan mempunyai nilai pelepasan sedang.

e. Angka Klasifikasi Resiko Bahaya

\section{Kebakaran 7}

Resiko bayaha kebakaran sangat rendah, dimana kuantitas dan kandungan bahan mudah terbakarnya sedang, tinggibtumpukan bahan mudah terbakarnya, dapat diperkirakan berkembang sedang, dan mempunyai nilai pelepasan panas rendah. 
Tabel 2

Angka Klasifikasi Resiko Bahaya Kebakaran Sedang (5), Rendah, dan Sangat Rendah (7)

\begin{tabular}{|c|c|c|c|}
\hline \multirow{2}{*}{ No } & \multicolumn{3}{|c|}{ Peruntukan Bangunan } \\
\hline & AKR 5 & AKR 6 & AKR \& \\
\hline 1 & $\begin{array}{l}\text { Tempat } \\
\text { Hiburan }\end{array}$ & Gudang minyak & $\begin{array}{l}\text { Apartemen, } \\
\text { rumah susun, } \\
\text { perumahan, } \\
\text { asrama }\end{array}$ \\
\hline 2 & $\begin{array}{l}\text { Gudang } \\
\text { pendingin, } \\
\text { Gudang hasil } \\
\text { pertanian, } \\
\text { Gudang } \\
\text { tembakau }\end{array}$ & Parkir mobil & $\begin{array}{l}\text { Universitas, } \\
\text { sekolah }\end{array}$ \\
\hline 3 & $\begin{array}{l}\text { Ruang pamer } \\
\text { dagang }\end{array}$ & $\begin{array}{l}\text { Pabrik roti, } \\
\text { pabrik bata, } \\
\text { pabrik kembang } \\
\text { gula }\end{array}$ & $\begin{array}{l}\text { Pos } \\
\text { kebakaran }\end{array}$ \\
\hline 4 & Binatu & $\begin{array}{l}\text { Tempat potong } \\
\text { rambut }\end{array}$ & Rumah sakit \\
\hline 5 & $\begin{array}{l}\text { Perpustakaan } \\
\text { (dengan gudang } \\
\text { buku yang besar }\end{array}$ & Rumah ibadah & $\begin{array}{l}\text { Hotel dan } \\
\text { sejenisnya }\end{array}$ \\
\hline 6 & Kios sablon & $\begin{array}{l}\text { Tempat praktek } \\
\text { dokter }\end{array}$ & $\begin{array}{l}\text { Perpustakaan } \\
\text { (tanpa } \\
\text { gudang buku) }\end{array}$ \\
\hline 7 & $\begin{array}{l}\text { Toko mesin, } \\
\text { toko besi }\end{array}$ & Tungku/dapur & Museum \\
\hline 8 & Asrama perawat & Pomp bensin & Perkantoran \\
\hline 9 & Percetakan & Kamar mayat & Kantor polisi \\
\hline 10 & Rumah makan & $\begin{array}{l}\text { Gedung } \\
\text { pemerintah, } \\
\text { kantor pos, } \\
\text { kantor telpon }\end{array}$ & \\
\hline 11 & $\begin{array}{l}\text { Bangunan } \\
\text { kososng }\end{array}$ & $\begin{array}{l}\text { Rumah potong } \\
\text { hewan }\end{array}$ & Penjara \\
\hline $\begin{array}{l}\text { Sun } \\
\text { Ket } \\
\text { di } \\
\text { ban }\end{array}$ & $\begin{array}{l}\text { er : Kepmen } P \\
\text { tuan Teknis } M c\end{array}$ & $\begin{array}{l}\text { No. } 11 \text { Tahun } \\
\text { zajmen Pemad } \\
\text { laikan dengan } \\
\text { bok Timur }\end{array}$ & $\begin{array}{l}\text { oo Tentang } \\
\text { Kebakaran } \\
\text { peruntukan }\end{array}$ \\
\hline
\end{tabular}

\section{Klasifikasi Kebakaran Berdasarkan Kontruksi Bangunan}

Klasifikasi kebakaran berdasarkan kontruksi bangunan dikelompokan ke dalam 4 (empat) kelas sebagai berikut:

\section{a. Resiko Kebakaran Kontruksi Tipe I (Kontruksi Tahan Api)}

Bangunan yang dibuat dengan bahan tahan api (beton, bata dan lain-lain dengan bahan logam yang dilindungi) dengan struktur yang dibuat sedemikian rupa, sehingga tahan terhadap peruntukan dan perambatan api mempunyai angka klasifikasi o,5.

b. Resiko Kebakaran Kontruksi Tipe II (Tidak Mudah Terbakar, Kontruksi Kayu Berat)

Bangunan yang seluruh bagian kontruksinya (termasuk dinding, lantai dan atap) terdiridari bahan tidak mudah terbakar yang tidak termasuk sebagai bahan tahan api, termasuk bangunan kontruksi kayu dengan dinding bata, tiang kayu
$20,3 \mathrm{~cm}$, lantai kayu $76 \mathrm{~mm}$, atap kayu $51 \mathrm{~mm}$, balok kayu 15,2 x 25,4 cm, ditetapkan mempunyai angka klasifikasi kontruksi o,8.

c. Resiko Kebakaran Kontruksi Tipe III (Biasa)

Bangunan dengan dinding luar bata atau bahan tidak mudah terbakar lainnya sedangkan bagian bangunan lainnya terdiri dari kayu atau bahan yang mudah terbakar ditentukan mempunyai angka klasifikasi kontruksi 1,0.

d. Resiko Kebakaran Kontruksi Tipe IV (Kerangka Kayu)

Bangunan (kecuali bangunan rumah tinggal) yang strukturnya sebagian atau seluruhnya terdiri dari kayu atau bahan mudah terbakar yang tidak tergolong dalam kontruksi biasa (tipe III) ditentukan mempunyai angka klasifikasi kontruksi 1,0.

\section{Teknik Gravitasi Ruang}

Modal gravitasi ini dapat digunakan untuk menganalisis interaksi dalam ruang, sehingga dapat diperguanakan untuk merencanakan prasarana perhubungan dan merencanakan letak pusat pelayanan. Menurut Blakely (1994:105) bahwa penggunaan Teknik ini akan dapat menghitung kekuatan relative dari hubungan komersial antara pusat pertumbuhan yang satu dengan pusat pertumbuhan yang lainnya (Suwardjo Warpani,1984:111).

$$
\begin{array}{ll|l} 
& \text { Dimana : } \\
\mathrm{I}_{12}=\mathrm{a} & \underline{\mathrm{P}_{12}=\text { Interaksi antar wilayah 1 dan 2 }} \\
\mathrm{J}_{1} \underline{\mathrm{P}}_{2} & \begin{array}{l}
\mathrm{P}_{1}=\text { Jumlah penduduk wilayah 1 } \\
\mathrm{P}_{2}=\text { Jumlah penduduk wilayah 2 } \\
\mathrm{J}_{12}
\end{array} \\
& \begin{array}{l}
\mathrm{a}=\text { jarak antara wilayah 1 dan 2 (dalam meter) } \\
\mathrm{b}=\text { Suatu ekponen jarak (ditetapkan 2) }
\end{array}
\end{array}
$$

\section{Persamaan 1}

Model Gravitasi Ruang

\section{ANALISIS \& PEMBAHASAN}

Menetukan WMK dengan menganalisis secara individual dan teruintegrasi atas probabilitas dan konsekuensi kebakaran untuk mendapatkan peta resiko kebakaran termasuk penentuan daerah layanan kebakaran yang di plot atau dituangkan secara geografis atas WMK-WMK dalam rangka menetapkan waktu tanggap sesuai persyaratan, serta menganalisis kondisi eksisting mengenai peta resiko kebakaran.

\section{Analisis Masalah Kebakaran}

Analisis factor strategis lingkungan internal atau Internal strategic factors analisis Sumarry (IFAS) bertujuan untuk mengetahui berbagai kemungkinan kekuatan dan kelemahan, sedangkan analisis factor 
strategis lingkungan eksternal atau external strategic Factors Analisis Sumarry (EFAS) untuk mengetahui berbagai kemungkinan peluang dan ancaman. Factor strategis yang dimaksud adalah factor dominan darielemen kekuatan, kelemahan, peluang dan ancaman yang memberikan pengaruh terhadap kondisi yang ada dan memberikan keuntungan bila dilakukan tindakan positif (Rangkuti F. 2008).

Tabel 3

Analisis Faktor-Faktor Internal Dan Eksternal Terkait Proteksi Kebakaran Di Wilayah Kab. Lombok Timur

\begin{tabular}{|c|c|}
\hline No. & Faktor-faktor Internal \\
\hline \multicolumn{2}{|c|}{ Kekuatan (Streght): } \\
\hline 1 & $\begin{array}{l}\text { Dukungan prasarana dan sarana yang efektif dan } \\
\text { efesien }\end{array}$ \\
\hline 2 & $\begin{array}{l}\text { Sertifikasi keahlian bagi anggota tim pemadam } \\
\text { kebakaran }\end{array}$ \\
\hline 3 & $\begin{array}{l}\text { Keberadaan manajemne proteksi kebakaran hingga } \\
\text { lingkup terkecil }\end{array}$ \\
\hline 4 & $\begin{array}{l}\text { SDM (kemampuan, keahlian dan keterampilan) } \\
\text { personil pemadam kebakaran }\end{array}$ \\
\hline 5 & $\begin{array}{l}\text { Kesesuaian jumlah prasarana dan sarana proteksi } \\
\text { kebakaran }\end{array}$ \\
\hline 6 & Penagakan hukum yang sesuai aturan \\
\hline 7 & $\begin{array}{l}\text { Pemanfaatan waktu luang } \\
\text { pelatihan/penyukuhan }\end{array}$ \\
\hline \multicolumn{2}{|r|}{ Kelemahan (Weakness) } \\
\hline 1 & $\begin{array}{l}\text { Keberadaan NSPM tentang proteksi kebakaran di } \\
\text { Kabupaten Lombok Timur }\end{array}$ \\
\hline 2 & Ketersediaan Prosedur Oprasional Standar (POS) \\
\hline 3 & $\begin{array}{l}\text { Kesesuaian jumlah personil (PPNS) menurut } \\
\text { kebutuhan. }\end{array}$ \\
\hline No. & Faktor-faktor Eksternal \\
\hline \multicolumn{2}{|c|}{ Peluang (opportunity) } \\
\hline 1 & $\begin{array}{l}\text { Pola kemitraan aatu kerjasama antar instansi } \\
\text { pemadam kebakaran }\end{array}$ \\
\hline 2 & Pelaksanaan kompetensi keahlian teknis \\
\hline 3 & Penyelanggaraan edukasi public bagi masyarakat \\
\hline 4 & $\begin{array}{l}\text { Ketersediaan aksesibilitas unit pemadan dan tempat } \\
\text { pengungsian }\end{array}$ \\
\hline 5 & Pasokan cadangan air \\
\hline 6 & $\begin{array}{l}\text { Pemahaman masyarakat tentang proteksi pemadam } \\
\text { kebakaran }\end{array}$ \\
\hline \multicolumn{2}{|c|}{ Ancaman (Threat) } \\
\hline 1 & Jaringan kerjasama dengan instansi lain \\
\hline 2 & Kegiatan pemeriksaan dalam gedung oleh IPK \\
\hline 3 & Aksesibilitas yang susah di jangkau \\
\hline 4 & Penyelenggaraan MPK yang sesuai dengan NSPM \\
\hline
\end{tabular}

\section{Analisis Pola Kejadian Kebakaran} WilayahKab. Lombok Timur

Pola kebakaran dapat diketahui dengan melihat penyebab kebakaran, jenis peruntukanyang terbakar, waktu kejadian, dan klasifikasi kebakaran dalam kurun waktu beberapa tahun terakhir. Dengan mengetahui pola keajaiban kebakaran terutama penyebab dan jenis peruntukan yang terbakar, maka dapat direncanakan upaya pencegahan dan penanggulangan kebakaran.

\section{Penyebab Kebakaran}

Secara umum, faktor penyebab kebakaran dapat dibedakan menjadi 2 (dua), yaitu faktor teknis dan faktor manusia. Faktor teknis umumnya diluar kendali manusia, namun dapat diupayakan pencegahannya seperti hubungan pendek arus listrik/ konsleting (BPBD Kab. Lombok Timur).

Sedangkan faktor manusia timbul akibat kelalaian manusia dan bisa dicegah. Berdasarkan data series kejadian kebakaran, kebakaran di Kab. Lombok Timur sebagian besar disebabkan oleh kebakaran yang menimpa Oven Tembakau, akibat dari meningkatnya tempratur tungku pemanas oven tembakau yang tidak terkendali. Kasus ini dari tahun ketahun mengalami kenaikan seiring dengan meningkatnya jumlah masyarakat yang menggantungkan hidupnya pada hasil perkebunan ini. Pada dasarnya kasus kebakaran yang terjadi bersifat fluktuatif dengan pola yang tidak bisa ditentukan.

\section{Tabel 4}

Kasus Kejadian Kebakaran Berdasarkan Penyebab Kebakaran di Wilayah Kab. Lombok Timur Tahun 2014 - 2016

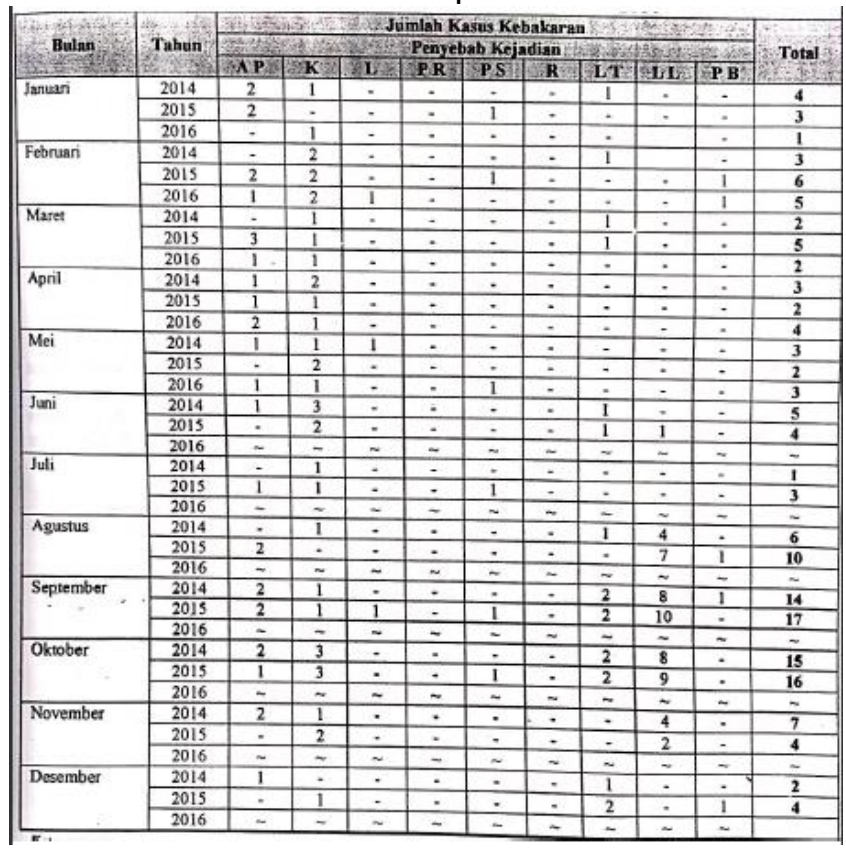

Sembilan penyebab di wilayah Kabupaten Lombok Timur apa bila diakumulasiakan, maka dapat dikelompokan menjadifactor teknis (konsleting/hubungan arus pendek), factor manusia (kompor, lilin, punting rokok, pembakaran sampah, kerusuhan, lampu templek), factor lain (kasus lain), dan factor tidak di ketahui (kasus yang masih dalam penyelidikanpihak berwajib).Faktor-faktor ini membawa implikasi pada kejadian kebakaran yang diketahui penyebabnya dan kejadian kebakaran yang tidak diketahui penyebabnya. Factor kesalahan manusia (human error) paling banyak disebabkan oleh kompor, baik kompor minyak maupun gas, serta tungku dari peng-ovenan tembakau. 


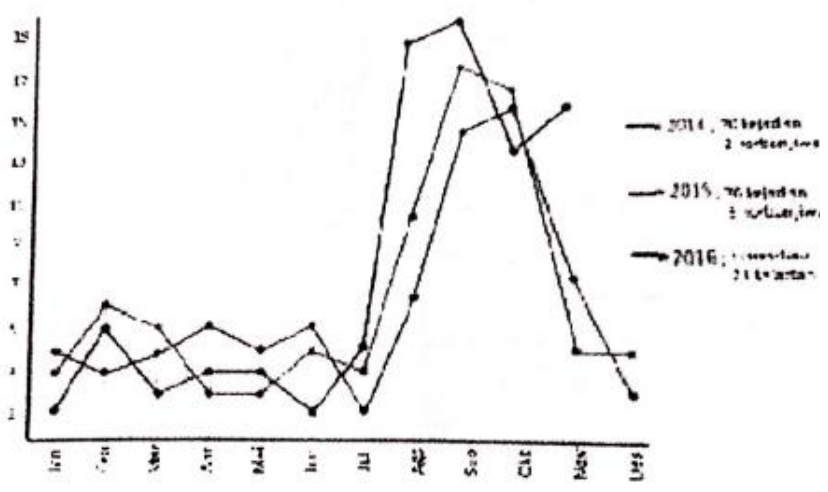

Grafik Kejadian Kebakaran di Wilayah Kab. Lombok Timur Tahun 2014-2016

\section{Pemanfaatan Lahan Rawan Kebakaran}

Peruntukan pemanfaatan lahan yang dikategorikan rawan kebakaran dapat berdasarkan frekuensi kejadian kebakaran, dianalisis dengan cara melihat kontruksi bangunan dan menentukan angka klasifikasi kebakaran, dan lebih ditekankan pada analisis kecendrungan peruntukan lahan yang memiliki potensi terbakar dalam beberapa tahun terakhir.

Tabel 5

Jenis peruntukan rawan kebakaran pada kasus kejadian kebakaran di wilayah Kab. Lombok Timur 2014-2015

\begin{tabular}{ccccc}
\hline \multirow{2}{*}{ No } & \multirow{2}{*}{ Jenis Peruntukan } & \multicolumn{3}{c}{ Tahun Kejadian } \\
\cline { 3 - 5 } & & $\mathbf{2 0 1 4}$ & $\mathbf{2 0 1 5}$ & $\mathbf{2 0 1 6}$ \\
\hline 1 & Oven Tembakau & 24 & 29 & - \\
2 & Rumah Tinggal & 17 & 27 & 9 \\
3 & Dapur & 8 & 6 & - \\
4 & Kantor & 1 & 2 & - \\
5 & Gudang tembakau & 4 & 2 & 1 \\
6 & Kebun & 2 & 4 & - \\
7 & Kandang & 3 & 1 & 1 \\
8 & Pengering gabah & 1 & 1 & - \\
9 & Pasar & 2 & 1 & - \\
10 & Kios & 5 & 2 & 2 \\
11 & bengkel & 3 & 1 & 1 \\
& Jumlah & $\mathbf{7 0}$ & $\mathbf{7 6}$ & $\mathbf{1 4}$ \\
\hline
\end{tabular}

Sumber : Hasil analisis

Keterangan :

*) Data Tahun 2016 hingga bulan November

Berdasarkan pada data sebelumnya, dapat diketahui bahwa peng-oven-an tembakau merupakan peruntukan yang paling sering mengalami kejadian kebakaran dan hal paling banyak disebabkan oleh factor kesalahan manusia. Data tersebut secara tidak langsung juga menjelaskan bahwa kerawanan akan bahaya kebakaran juga semakin tinggi. Pada tingkat berikutnya fasilitas perumahan, khususnya rumah tinggal, dimana kejadian kebakaran pada lokasi tempat tinggala ini lebih banyak disebabkan oleh konsleting arus pendek listrik dan akibat dari ledakan kompor.

\section{Analisis Waktu Kejadian Kebakaran}

Analisis waktu kejadian kebakaran berfungsi untuk mengetahui besarnya pasokan air yang dibutuhkan serta upaya penanggulangan yang perlu dilakukan sesuai dengan waktu-waktu terjadinya kebakaran. Asumsi waktu terhadap upaya panaggulangan kebakaran dapat dilihat dari tabel berikut

\section{Tabel 6}

Asumsi Waktu *) Terhadap Penanggulangan Kebakaran Wilayah kabupaten Lombok Timur

\begin{tabular}{|c|c|c|}
\hline $\begin{array}{l}\text { Dimensi } \\
\text { Waktu }\end{array}$ & $\begin{array}{c}\text { Debit Air } \\
\text { (liter/hari) }\end{array}$ & Aksesibilitas \\
\hline Pagi & $\begin{array}{l}\text { Penggunaan air pada } \\
\text { pagi hari sangat } \\
\text { tinggi karena } \\
\text { aktivitas dimulai } \\
\text { pada waktu ini. Oleh } \\
\text { sebab itu, pembagian } \\
\text { debit air untuk } \\
\text { pemadam kebakaran } \\
\text { juga sedikit }\end{array}$ & $\begin{array}{l}\text { Watu pagi merupakan } \\
\text { jam puncak awal untuk } \\
\text { bangikatan lalu lintas. } \\
\text { Pada waktu ini intensitas } \\
\text { berkendara cukup tinggi, } \\
\text { sehingga menyulitkan } \\
\text { mobil pamadam } \\
\text { kebakaran melalui jalan, } \\
\text { terutama jalan utama. }\end{array}$ \\
\hline Siang & $\begin{array}{l}\text { Beban penggunaan } \\
\text { air relatif berkurang, } \\
\text { sehingga debit air } \\
\text { untuk pemadam } \\
\text { kebakaran dapat } \\
\text { dioptimalkan } \\
\text { semaksimal mungkin }\end{array}$ & $\begin{array}{l}\text { Jalan-jalan tidak sepadat } \\
\text { waktu pagi, sehingga } \\
\text { dapat mempermudah } \\
\text { mobil pemadam } \\
\text { kebakaran menuju } \\
\text { kelokasi kebakaran. } \\
\text { Namun, apabila kejadian } \\
\text { kebakaran terjadi pada } \\
\text { jam puncak, maka akan } \\
\text { menyulitkan mobil } \\
\text { pemadam kebakaran } \\
\text { menuju lokasi kebakaran }\end{array}$ \\
\hline Sore & $\begin{array}{l}\text { Beban penggunaan } \\
\text { air relatif berkurang, } \\
\text { sehingga debit air } \\
\text { untuk pemadam } \\
\text { kebakaran dapat } \\
\text { digunakan seoptimal } \\
\text { mungkin }\end{array}$ & $\begin{array}{l}\text { Jalan-jalan mulai } \\
\text { cendrung padat kembali, } \\
\text { namun tidak terlalu } \\
\text { menyulitkan mobil } \\
\text { pemadam kebakaran } \\
\text { menuju lokasi kebakaran }\end{array}$ \\
\hline Malam & $\begin{array}{l}\text { Beban penggunaan } \\
\text { air relatif berkurang, } \\
\text { sehingga debit air } \\
\text { untuk pemadam } \\
\text { kebakaran dapat } \\
\text { digunakan seoptimal } \\
\text { mungkin. }\end{array}$ & $\begin{array}{l}\text { Jalan-jalan utama relatif } \\
\text { lenggang, sehingga } \\
\text { mempercepat mobil } \\
\text { pemadam kebakaran } \\
\text { menuju ke lokasi } \\
\text { kebakaran. }\end{array}$ \\
\hline
\end{tabular}

Sumber: hasil analisis

Keterangan:

*) Kondisi normal, bukan waktu khusus

\section{Analisis Transportasi}

Pada proses penentuan Wilayah Manajmen Kebakaran di Kabupaten Lombok Timur diperlukan analisis terhadap sisitem transportasi yang merupakan indicator kelancaran orang ataupun barang. Dengan menganalisis apa yang menjadi potensi dan masalah transportasi dan menghubungkan keduanya dengan tata guna lahan yang ada di Kabupaten Lombok Timur dan sekitarnya maka akan didapat rumusan/konsep pengembangan sistemtransportasi yang sesuai dengan kebutuhan.

Kondisi jalan yang ada di sepanjang Lombok Timur tergolong kurang sesuai terutama di sepanjang 
koridor jalan utama Mataram-Labuhan Lombok. Hal tersebut dikarnakan lebar jalan yang kurang mencapai 11 meter. Meskipun demikian pendekatan analisis tersebut tidak cukup pada kesesuaian lebar badan jalan berdasarkan satandar jalan, tetapi juga pada kapasitas jalan. Hal tersebut dilakukan agar kebijakan yang akan diambil dapat efektif. Jika hanya mengacu pada standar lebar jalan tentu kebijakan yang diambil pada jalan yang dengan lebar yang minimum akan dilakukan pelebaran jalan. Disepanjang jalan utama yang ada di Lombok Timur, terutama pada bagian sisi kanan dan kiri jalan pada umumnya sudah penuh dengan bangunan sehingga pelebaran jalan terlalu sulit untuk dilakukan. Oleh karna itu, diperlukan analisis lain pada jaringan jalan.

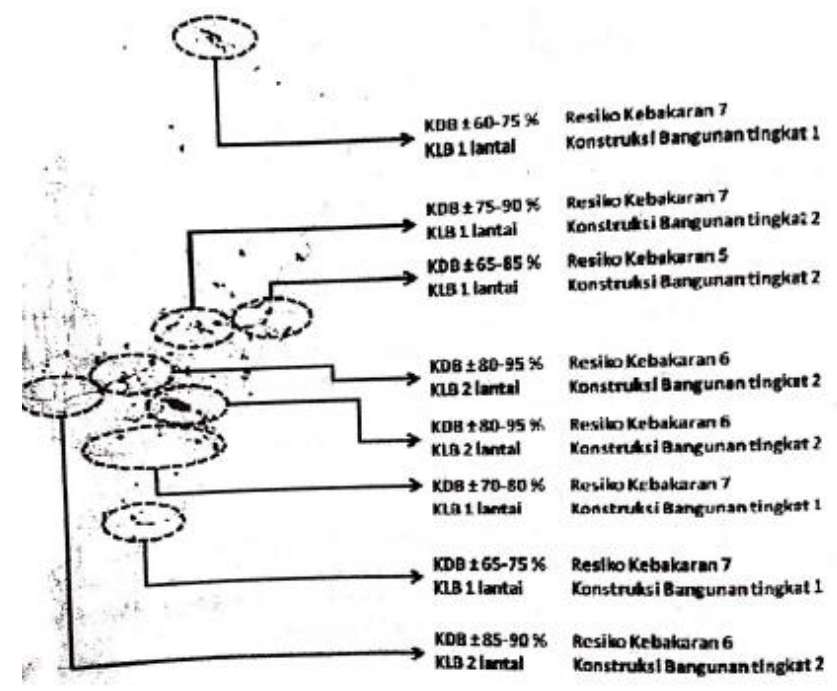

Gambar 1

Sebaran Kepadatan Bangunan, Klasifikasi Resiko Kebakaran

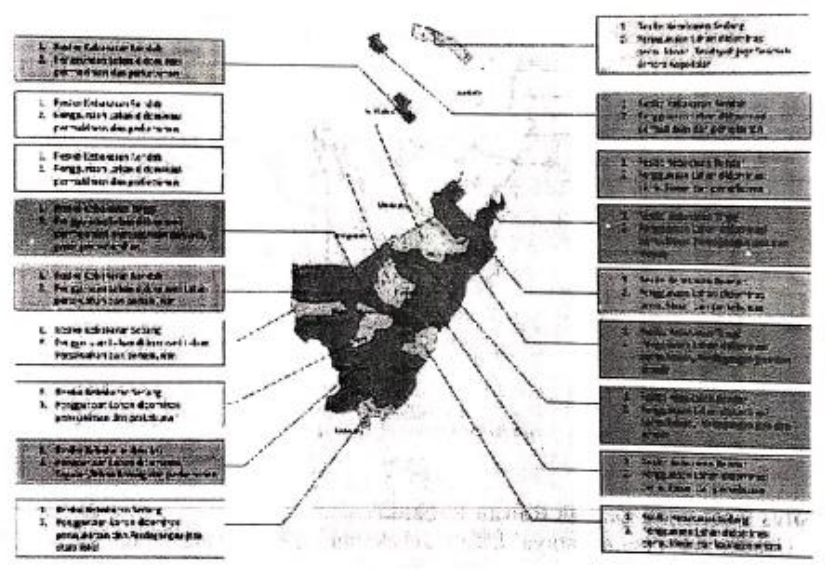

Gambar 2

Zona Rawan Kebakaran Berdasarkan Dominasi penggunaan Lahan

\section{Analisis Waktu Tanggap (Response Time)}

Kondisi geografis Kabupaten Lombok Timur sebagian besar wilayahnya merupakan wilayah yang memmiliki morfologi bergelombang dan berbukit. Hal ini sangat berpengaruh dalam penentuan MWK, sehingga factor Geografis akan menjadi pendukung dalam pemadam kebakaran. Seiring dengan perkembangan wilayah, maka pertambahan jumlah kendaraan juga akan mengalami peningkatan sehingga akan menambah beban jalan yang akhirnya akan mengakibatkan kemacetan. Beban jalan tersebut juga ditambah dengan adanya titik-titik keramaian akibat aktivitas pasar, yang menjang mulai dari jalur utama dibagian barat (Kecamatan Montong Gading), hingga jalur utama menuju Pelabuhan Kayangan (Kecamatan Pringgabaya). Kemacetan dijalan sering menghambat peroses pemadam kebakaran sehingga kerugian akibat kebakaran akan bertambah banyak.

Kondisi Lalu lintas, terutama lalu lintas jalan raya, akan berpengaruh pada waktu tanggap (response time). Response time yang telah dipakai oleh UPT kebakaran Kabupaten Lombok Timur secara rata-rata waktu hingga saat ini adalah \pm 35 menit yang terdiri dari :

- Waktu dimulai sejak diterimanya pemberitahuan adanya kebakaran di suatu tempat, interprestasi penentuan lokasi kebakaran dan penyiapan pasukan serta sarana pemadaman selama \pm 10 menit.

- Waktu perjalanan dari pos pemadam menuju lokasi selama \pm 20 menit.

- Waktu gelar peralatan dilokasi sampai dengan siap oprasi penyemprotan selama \pm 5 menit.

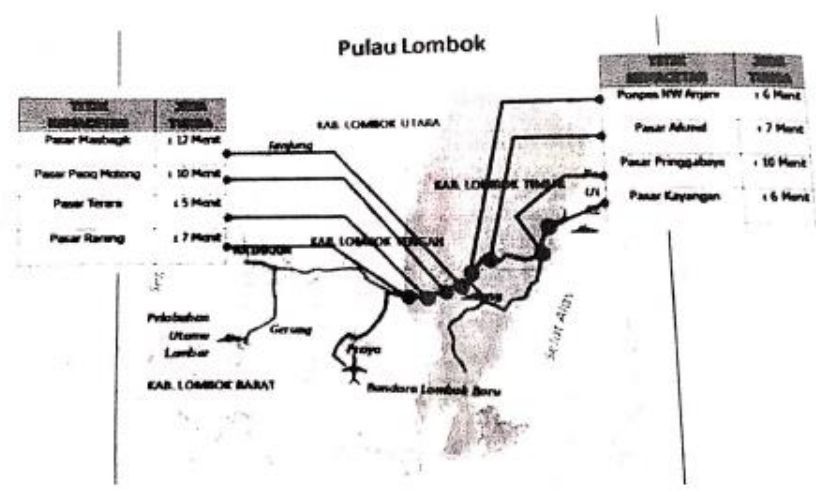

Gambar 3

Titik Rawan Kemacetan, Jalur utama

\section{Intensitas Kasus Dan Daerah Rawan Kebakaran}

Cendrung meningkatnya kesusukebakaran di Kabupaten Lombok Timur dan mayoritas sering tidak terdekteksi yaitu pada unused area(rumput ilalalng, sampah), serta kejadian kebakaran pada bangunan perumahan, bangunan perdagangan (pasar), serta bangunan industri. Selama ini, daerah yang rawan kebakaran adalah di pusat perkotaan di seluruh wilayah Kabupaten Lombok Timur, daerah tersebut merupakan daerah padat permukiman. Daerahdaerah tersebut selama ini untuk penanganan kebakaran hanya dilayani oleh 1 pos pemadam 
kebakaran, namun dengan aturan dari regulasi yang mengatur radius pelayanan $7,5 \mathrm{~km}$, maka akan sulit diterapkan di wilayah Kabupaten Lombok Timur, karna luas wilayah yang besar, serta kondisi geografis wilayah yang sangat sulit untuk melakukan perjalanan dengan cepat dan tepat waktu ke wilayah yang terjadi kebakaran.

\section{Kondisi Geografis dan Morfologi Wilayah}

Wilayah Manajmen Kebakaran (MWK) yang telah ditentukan di Kabupaten Lombok Timur cendrung tidak mengikuti aturan dasar yang berlaku pada KepmenPU No. 10 dan 11 tahun 2000 yang mensyaratkan response time (waktu tanggap) dan jarak jangkau pelayanan masing-masing 15 dan 7,5 meter radius layanan, dikarnakan luas wilayah Kabupaten Lombok Timur yang sangat besar. Selain itu, kondisi akses jalan yang cendrung linier dan kawasan terbangun yang mengikut jalan utama, mengakibatkan akan sulit untuk menentukan MWK menggunakan parameter-parameter tersebut diatas, maka capaian petugas PMK menuju lokasi kebakaran tidak mampu dengan cepat dan memiliki hambatan yang tinggi.

Dari hasil pengamatan lapangan dan analisis pada peta topografi wilayah dengan melihat bentukan morfologi wilayah tiap kecamatan, maka akan dibagi beberapa kecamatan menjadi beberapa interval jenis yaitu wilayah morfologi dengan kondisi geografis yang terjal, bergelombang, dan landai; serta akses baik dan tidak memiliki aksesibilitas yang baik. Kecamatan tersebut yaitu :

Tabel 7

Kondisi Morfologi \& akses Wilayah Kecamatan SeKab. Lombok Timur

\begin{tabular}{lcc}
\hline \multicolumn{1}{c}{ Kecamatan } & Morfologi & $\begin{array}{c}\text { Aksesibilitas } \\
\text { Wilayah }\end{array}$ \\
\hline Aikmel & Landai & Baik \\
Jerowaru & Bergelombang & Kurang Baik \\
Keruak & Bergelombang & Kurang Baik \\
Labuhan Haji & Landai & Baik \\
Masbagik & Landai & Baik \\
Montong Gading & Bergelombang & Kurang Baik \\
Pringgabaya & Bergelombang & Baik \\
Pringgasela & Bergelombang & Kurang Baik \\
Sakra & Landai & Baik \\
Sakra Barat & Bergelombang & Baik \\
Sakra Timur & Bergelombang & Kurang Baik \\
Sambelia & Terjal & Kurang Baik \\
Selong & Landa & Baik \\
Sembalun & Terjal & Kurang Baik \\
Sikur & Landai & Baik \\
Suela & Terjal & Kurang Baik \\
Sukamulya & Landai & Baik \\
Suralaga & Landai & Baik \\
Terara & Landai & Baik \\
Wanasaba & Bergelombang & Kurang Baik \\
\hline Sumber:Analiang
\end{tabular}

Sumber: Analisis Topografi dan Analisis Jalan 2015

\section{1o. Penentuan Wilayah Manajmen Kebakaran (MWK)}

Wilayah manajmen kebakaran di wilayah Kabupaten Lombok Timur secara umum dibagi beradsarkan klasifikasi resiko kebakaran, jangkauan pelayanan stasiun/pos pemadam kebakaran, waktu tanggap (response time) dan pendeketan model gravitasi keterkaitan antara pusat kegiatan di Kabupaten Lombok Timur.

Tabel 8

Matriks Analisis Penanganan Kebakaran

\begin{tabular}{clccc}
\hline No. & Kecamatan & Resiko & Jangkauan* & $\begin{array}{c}\text { Waktu } \\
\text { Tanggap }\end{array}$ \\
\hline 1 & Aikmel & Tinggi & Sedang & 25 menit \\
2 & Jerowaru & Tinggi & Dekat & 15 menit \\
3 & Keruak & Sedang & Dekat & 15 menit \\
4 & Lab. Haji & Tinggi & Dekat & 13 menit \\
5 & Masbagik & Tinggi & Dekat & 15 menit \\
6 & Mt. Gading & Sedang & Jauh & 55 menit \\
7 & Pringgabaya & Sedang & Sedang & 35 menit \\
8 & Pringgasela & Rendah & Jauh & 40 menit \\
9 & Sakra & Tinggi & Sedang & 18 menit \\
10 & Sakra Barat & Sedang & Sedang & 25 menit \\
11 & Sakra Timur & Sedang & Sedang & 20 menit \\
12 & Sambelia & Sedang & Dekat & 15 menit \\
13 & Selong & Tinggi & Dekat & 10 menit \\
14 & Sembalun & Rendah & Jauh & 68 menit \\
15 & Sikur & Tinggi & Jauh & 30 menit \\
16 & Suela & Rendah & Jauh & 35 menit \\
17 & Sukamulya & Sedang & Dekat & 17 menit \\
18 & Suraiga & Sedang & Sedang & 20 menit \\
19 & Terara & Tinggi & Jauh & 35 menit \\
20 & Wanasaba & Rendah & Jauh & 40 menit \\
\hline
\end{tabular}

Sumber : hasil analisis

*) Berdasarkan Lokasi Pos Terdekat

(Kota Selong Kec. Sambelia dan Kec. Keruak)**) Kec. Ratarata $60 \mathrm{~km} / \mathrm{jam}$

Sedangkan untuk matrik berdasarkan pendekatan gravitasi ruang, menunjukan beberapa wilyah administrasi yang memiliki keterkaitan yang sangat kuat, dan beberapa wilayah administrasi cendrung keterkaitan pada masiang-masing wilayahnya tidak ada, sehingga diasumsikan bahwa wilayah tersebut akan melayani wilayah itu sendiri. 
Tabel 9

Matrik Gravitasi Kecamatan Kab. Lombok Timur
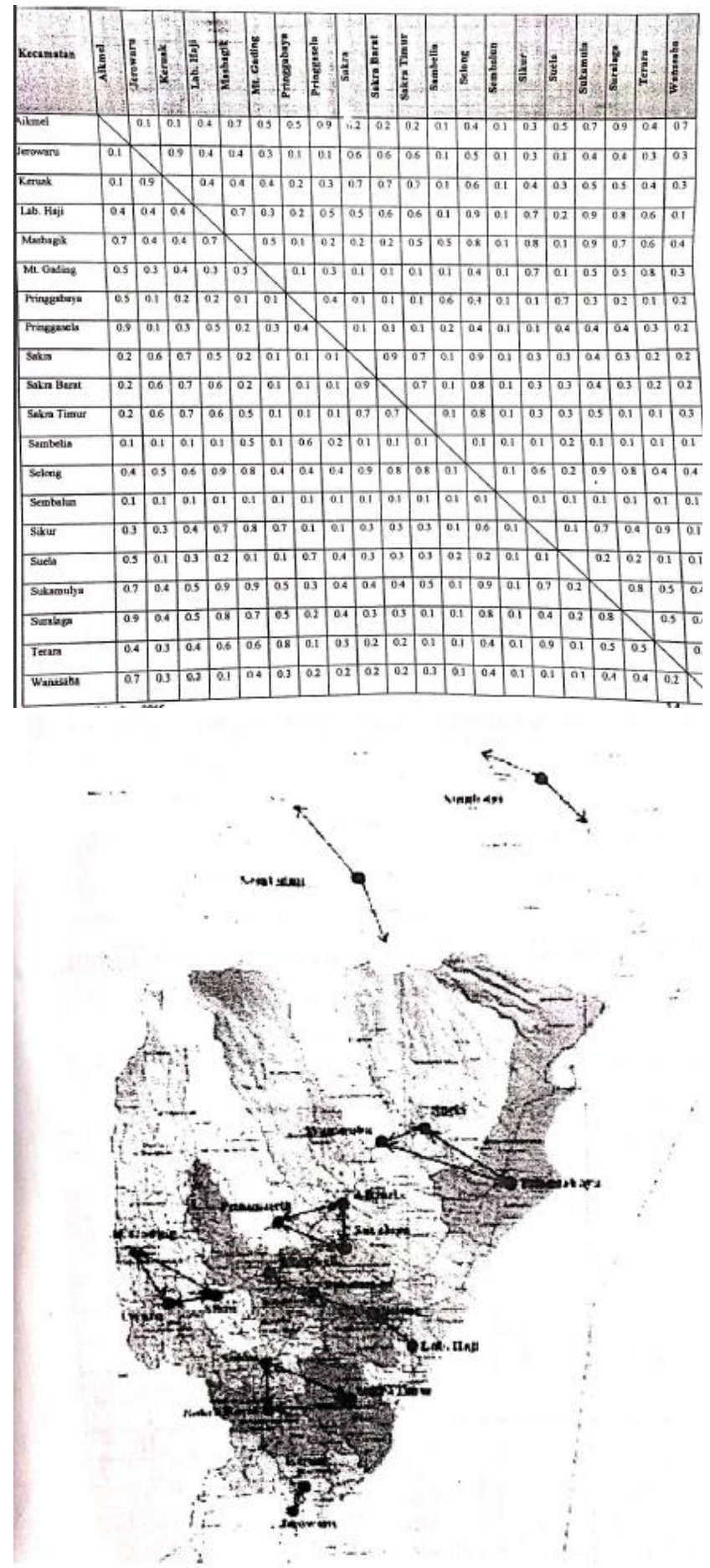

Gambar 4

Simulasi Model Gravitasi

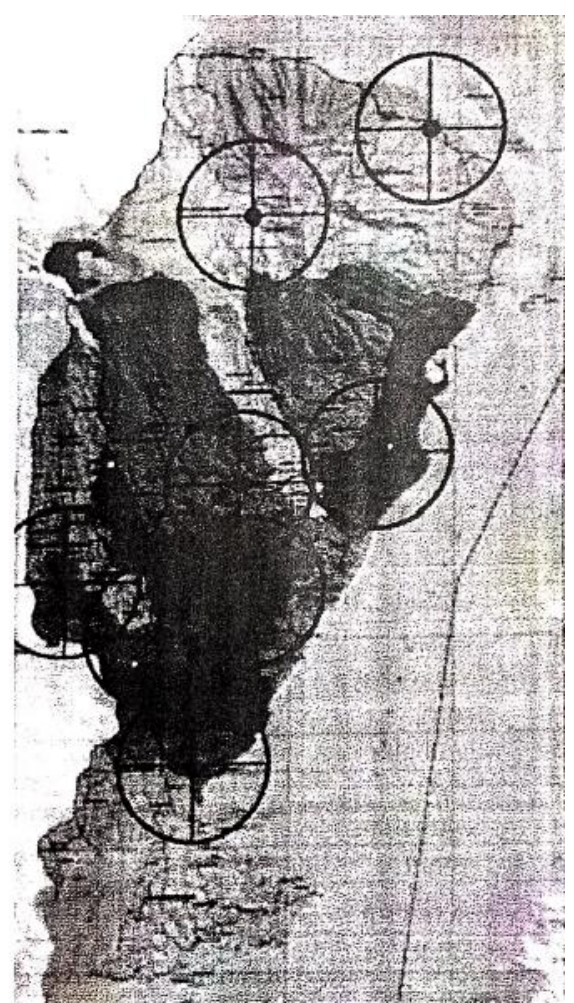

Gambar 5

Jangkauan Layanan MWK

MWK dibagai berdasarkan batas administrasi kecamatan mengingat program kegiatan instansi pemadam kebakaran Kabupaten Lombok Timur dilaksanakan pada tiap-tiap kecamatan untuk memudahkan pengendalian dan pengontrolan upaya proyeksi kebakaran wilayah kota. MWK tersebut adalah :

1. MWK aikmel

2. MWK Keruak

3. MWK peringgabaya

4. MWK Sakra

5. MWK Sambelia

6. MWK selong

7. MWK Sembalun

8. MWK Terara

\section{Prioritas MWK}

Hingga saat ini, wilayah Kab. Lombok Timur hanya memiliki satu unit induk pospemadam kebakaran yang melayani hampir seluruh kecamatan dengan 2 unit cabang yang berada di Kecamatan Jerowaru dan Kecamatan Sambelia.

Pada dasarnya seluruh kawasan di wilayah Kabupaten Lombok Timur memiliki prioritas yang sama dalam upaya proteksi kebakaran, namun penentuan MWK lebih ditunjukan untuk menentukan prioritas lokasi.

Penentuan WMK dibagi berdasarkan batas administrasi wilayah kecamatan untuk memudahkan dalam perencanaan, pengendalian, dan evaluasi. Indicator dalam menentukan prioritas WMK, yang terdiri dari : 
- Resiko Kebakaran;

- Kepadatan Bangunan;

- Jangkauan Pos Pemadam Kebakaran; dan

- Fungsi Strategis Wilayah.

Untuk lebih jelasnya mengenai penilaian prioritas WMK berdasarkan skoring pembobotan, dapat dilihat pada tabel berikut ini (sudrajta, 2005)

Tabel 10

Pembobotan Penentuan Prioritas WMK Kab. Lombok Timur

\begin{tabular}{|c|c|c|c|c|c|c|c|}
\hline \multirow{2}{*}{$\begin{array}{c}\text { No } \\
\text {. }\end{array}$} & \multirow{2}{*}{$\begin{array}{c}\text { WM } \\
\mathbf{K}\end{array}$} & \multicolumn{4}{|c|}{ Indicator } & \multirow{2}{*}{$\begin{array}{c}\text { Tot } \\
\text { al } \\
\text { Sk } \\
\text { or }\end{array}$} & \multirow{2}{*}{$\begin{array}{c}\text { priori } \\
\text { tas }\end{array}$} \\
\hline & & $\begin{array}{c}\text { Resiko } \\
\text { Kebaka } \\
\text { ran }\end{array}$ & $\begin{array}{c}\text { Kepad } \\
\text { atan } \\
\text { Bangu } \\
\text { nan }\end{array}$ & $\begin{array}{c}\text { Jaang } \\
\text { kauan } \\
\text { Pos } \\
\text { WMK }\end{array}$ & $\begin{array}{c}\text { Fungsi } \\
\text { strateg } \\
\text { is } \\
\text { Wilaya } \\
\text { h }\end{array}$ & & \\
\hline 1 & $\begin{array}{c}\text { Aikm } \\
\text { el }\end{array}$ & 2 & 3 & 2 & 2 & 9 & III \\
\hline 2 & $\begin{array}{c}\text { Keru } \\
\text { ak }\end{array}$ & 1 & 1 & 2 & 2 & 6 & VI \\
\hline 3 & $\begin{array}{c}\text { Pring } \\
\text { gaba } \\
\text { ya }\end{array}$ & 2 & 2 & 3 & 1 & 8 & IV \\
\hline 4 & $\begin{array}{c}\text { Sakr } \\
\mathrm{a}\end{array}$ & 2 & 2 & 2 & 1 & 7 & $\mathrm{~V}$ \\
\hline 5 & $\begin{array}{l}\text { Sam } \\
\text { belia }\end{array}$ & 1 & 1 & 3 & 1 & 6 & VII \\
\hline 6 & $\begin{array}{c}\text { Selon } \\
\mathrm{g}\end{array}$ & 3 & 3 & 2 & 3 & 11 & I \\
\hline 7 & $\begin{array}{l}\text { Semb } \\
\text { alun }\end{array}$ & 1 & 1 & 3 & 1 & 6 & VIII \\
\hline 8 & $\begin{array}{c}\text { Terar } \\
\mathrm{a}\end{array}$ & 3 & 2 & 3 & 2 & 10 & II \\
\hline \multicolumn{2}{|c|}{$\begin{array}{c}\text { Parameter } \\
\text { Skor }\end{array}$} & $\begin{array}{c}\text { Tinggi }= \\
3 \\
\text { Sedang } \\
=2 \\
\text { Rendah } \\
=1\end{array}$ & $\begin{array}{c}\text { Rapat }= \\
3 \\
\text { Sedang } \\
=2 \\
\text { Rengga } \\
\text { ng }=1\end{array}$ & $\begin{array}{c}\text { Jauh = } \\
3 \\
\text { Sedang } \\
=2 \\
\text { Dekat }= \\
1\end{array}$ & $\begin{array}{c}\text { Strategi } \\
\mathrm{s}=3 \\
\mathrm{Krg} \\
\text { Strategi } \\
\mathrm{s}=2 \\
\text { Tdk } \\
\text { Strategi } \\
\mathrm{s}=1\end{array}$ & & \\
\hline
\end{tabular}

Sumber : Pengelolahan Hasil Analisis

Berdasarkan analisis penentuan WMK dengan berbagai indikatornya, maka nilai akumulasi dari seluruh indikator tersebut menghasilkan wilayah manajmen kebakaran berdasarkan hirarki pelayanannya yaitu :
1. MWK I
: MWK Selong
2. MWK II
: MWK Terara
3. MWK III
: MWK Aikmel
4. MWK IV
: MWK Pringgabaya
5. MWK V
: MWK Sakra
6. MWK VI
: MWK Keruak
7. MWK VII
: MWK Sambelia
8. MWK VIII

Untuk lebih jelasnya mengenai pembagian Wilayah Manajmen Kebakaran (WMK) Kab. Lombok Timur, dapat dilihat pada gambar pembagian WMK.

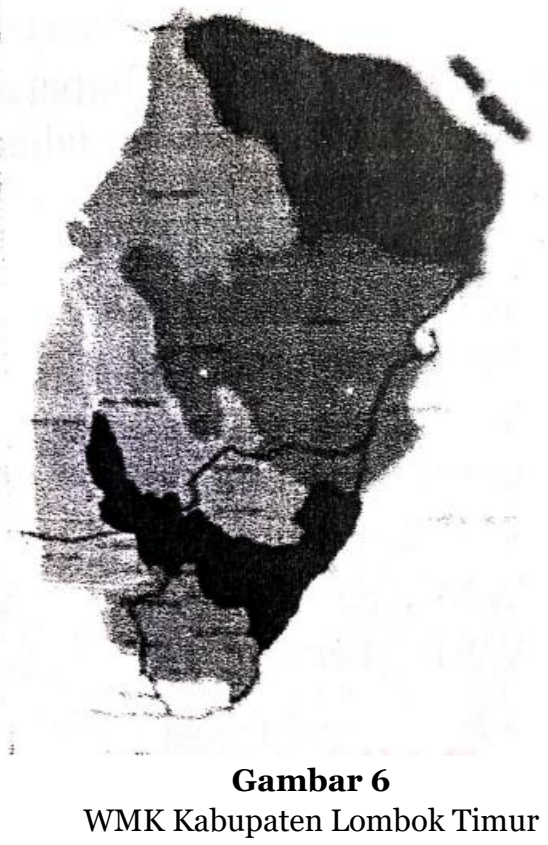

\section{KESIMPULAN}

Dari pembahasan sebelumnya, dapat ditarik kesimpulan bahwa Kabupaten Lombok Timur saat ini bemum memiliki suatu pengolaan penanggulangan kebakaran yang optimal terkait antisipasi dan waktu tanggapdalam melakukan kegiatan pemadaman di lokasi kebakaran. Hal ini terjadi akibat infrastruktur pemadam kebakaran yang belum memadai dan keterbatasan waktu tanggap (response time) petugas dari IPK yang belum memenuhi standar teknis pemadam kebakaran.

Waktu tanggap dalam penanganan kebakaran, sesuai dengan standar teknis penanganan kebakaran (sumber : Peraturan Mentri Pekerjaan Umum No. 25/PRT/M/2008 Tentang Pedoman Teknik Penyusunan Rencana Induk Sistem Kebakaran), waktu tanggap yang harus dicapai petugas pemadam kebakaran adalah 15 menit sejak diterimanya laporan kejadian kebakaran, terdiri dari 5 menit pertama untuk persiapan armada dan personil, 5 menit kedua waktu tempuh armada pemadam kebakaran menuju lokasi kebakaran, dan 5 menit terakhir digunakan untuk gelar pasukan dan armada di lokasi kejadian kebakaran.

Untuk mencapai waktu tanggap yang optimal tersebut, maka disusunlah suatu pendekatan penanggulangan kejadian kebakaran didasarkan pada areal penanganan kebakaran berupa Wilayah Manajmen Kebekaran (WMK) WMK di Kabupaten Lombok Timur, berdasarkan hasil pembahasan, ditetapkan sebanyak 8 WMK, berdasarkan karakteristik wilayah dan resiko penanganan 
kebakaran di masing-masingwilayah kecamatan di Kabupaten Lombok Timur.

Wilayah Manajmen Kebakaran (WMK) yang telah di tetapkan, diberikan bobot untu mengetahui hierarki WMK dengan indictor penentuan prioritas WMK berdasarkan resiko Kebakaran, Kepadatan Bangunan, Jangkauan Pos Pemadam Kebakaran dan Fungsi Strategis Wilayah.

\section{DAFTAR PUSTAKA}

\section{Buku}

[1] Hasan, M. Iqbal, 2002, Pokok-pokok Materi Metodelogi Penelitian \& Aplikasinya, Ghalia Indonesia, Jakarta

[2] Rangkuti F. 2008, Analisis SWOT Teknik Membedah Kasus Bisnis, PT Gramedia Pustaka Utama, Jakarta

[3] Sudrajat, 2005, Materi Kota Kuliah Umum Kedinasan : Pengambilan Keputusan, Badan Pembina Konstruksi dan Sumber Daya Manusia, Departemen Pekerjaan Umum, Jakarta

[4] Warpani, Suwardjoko, 1984, Analisis Kota \& Daerah, Penerbit ITB, Bandung

\section{Artikel/Modul/Diktat}

[5] BPS Kab. Lombok Timur, 2014, Kabupaten Lombok Timur Dalam Angka, Badan Pusat Statistik Kab. Lombok Timur, Selong

[6] Dpartemen Kimprawil, 2000, Pedoman Penataan Bangunan Gedung, Direktorat Jendral Cipta Karya, Dparemen Kimprawil, Jakarta

[7] Dinas Pekerjaan Umum Prov. Nusa Tenggara Barat, 2013, Dokumen Pemeliharaan Jalan Nasional, Dinas Pekerjaan Umum Provinsi Nusa Tenggara Barat, Mataram

[8] Kantor Badan Penanggulangan Bencana Daerah (BPBD), 2015, Dokumen Laporan Bencana Kebakaran Kabupaten Lombok Timur, Bidang Penanggulangan Bencana, Selong

[9] Keputusan Mentri Pekerjaan Umum No. 11/KPTS/2000 tentang Ketentuan Teknis Manajmen Penanggulangan Kebakaran di Perkotaan, Jakarta

[10] Peraturan Mentri Pekerjaan Umum No. 25/PRT/M/2008 Tentang Pedoman Teknik Penyususnan Rencana Induk Sistem Kebakaran, Jakarta. 